\title{
Clandestine Classics: Isaac Orobio and the Polemical Genre among the Dutch Sephardim
}

Studies on the intellectual history of the Portuguese Jews in seventeenth-century Amsterdam sometimes compare the gentleness and open-mindedness of Rabbi Menasseh ben Israel (1604-1657) with the militantly polemical spirit that distinguished Doctor Isaac Orobio (c. 1617-1687) in order to juxtapose welcoming and reactionary Jewish attitudes towards modernity. Ralph Melnick unfolded a progressive narrative in which the harsh attacks upon Christianity that can be found at the beginning of the century in the Tratado of Dr. Elijah Montalto (1567-1616) and later in the works of his disciple Rabbi Saul Levi Mortera (1596-1660) "were slowly being replaced by a new approach" built on tolerance and mutual understanding, one exemplified by Ben Israel's Conciliador in $1632 .^{1}$

The Whiggish narrative of gradual "Jewish-Christian rapprochement" is edifying but chronologically unconvincing: both Mortera, who wrote most of his polemical works after Ben Israel, and Orobio, who only arrived in Amsterdam five years after the latter's death, expressed themselves once again in the trigger-happy polemical style that Amsterdam Jews had allegedly forsaken. The progress narrative account is even less convincing due to the fact that the peak of Montalto's literary success coincided with Orobio's at the turn of the eighteenth century, when their clandestine opera omnia were manually copied by the dozens among the Amsterdam Jews.

Shall we rather say, then, that the intellectual history of Jewish Amsterdam is permanently torn between the poles of Manassean brotherhood and Orobian xenophobia? This is what Jesué Pinharanda Gomes tried to suggest in a chapter of his History of Portuguese Philosophy, which was published in 2001. He classified Orobio in the school of "Zionist integralism" (integralismo sionista) and painted Amsterdam Jewish thought in black-and-white colours: "Menasseh and Orobio adhere to contrasting theories: an obstinate anti-Christian ideology on the side of Orobio, and a manifest sense of openness on the side of Menasseh, embracing the unity of Jewish heritage with all its differences, a heritage of which even the Church is considered to be a part."2

Carsten Wilke, Central European University Budapest

1 Ralph Melnick, From Polemics to Apologetics: Jewish-Christian Rapprochement in Seventeenth-Century Amsterdam (Assen: Van Gorcum, 1981), 45.

2 J. Pinharanda Gomes, "Messianologia e integralismo sionista: Menassé ben Israel e Oróbio de Castro," in História do pensamento filosófico português, vol. II, edited by Pedro Calafate (Renascimento e Contra-Reforma, Lisbon: Caminho, 2001): 262-271, here 270: "as teorias de Menassé e de Oróbio apresentam um carácter diferencial: um ostinado anticristianismo do lado de Oróbio, um sensível sentido 
This paper will question this binary scheme of exclusivism and tolerance by pointing to a simple fact that both Melnick and Pinharanda Gomes seem to have overlooked: the authors they tried to classify according to a schematic ideological juxtaposition wrote in different literary genres. Ben Israel published books that were destined to win an audience among various religious communities for a subtle theological compromise, whereas Montalto and Orobio authored clandestine manuscripts that were directed to Jews alone to immunise them against missionaries and make them feel proud of their faith. In sum, whoever pits the tolerant Ben Israel against the dogmatic Orobio compares apples with oranges. If the former's extant work belongs to the irenic genre and the latter's to the polemical one, then this choice of a generic convention is not necessarily due to some inherent psychological predilection of their authors' personalities but may, rather, reflect the expectations of their respective audiences, if not a selection of texts made by posterity.

We have indeed some interesting clues indicating that the writings that are transmitted under the names of both authors represent only a one-sided fragment of their oeuvre. In my edition of the Marrakesh Dialogues, an anonymous anti-Christian work originally written in 1583, I discovered that Ben Israel himself seems to have been responsible for one of the manuscript editions that was meant to give this Renaissance dialogue a linguistic and rhetorical facelift. ${ }^{3}$ It was thus apparently Menasseh ben Israel who spiced the already extremely provocative text with further broadsides, calling Christianity "madness" and its believers "ignoramuses." ${ }^{4}$ Orobio, as Yosef Kaplan has shown, participated in a frivolous poetic academy in Amsterdam, where he must have entertained himself and others in a literary register quite different from the theological polemics for which he would become famous. ${ }^{5}$

Let us now try to approach Orobio's place in Jewish thought from the perspective of genre theory, which started in 1980 with Jacques Derrida's article "The Law of Genre" 6 and led to the understanding of literary genres as open and historically moving structures that determine individual expressions while being determined by them. My reconstruction of these generic laws will considerably complicate the dogmatic phraseology that Jews of different personalities and persuasions knew to use in seventeenth-century Amsterdam.

de abertura do lado de Menassé quanto à unidade da herança judaica nas diferenças. Neste plano, a Igreja não pode deixar de considerar-se uma herança de Israel."

3 Carsten L. Wilke, The Marrakesh Dialogues: A Gospel Critique and Jewish Apology from the Spanish Renaissance (Leiden: Brill, 2014), 174-175.

4 Wilke, The Marrakesh Dialogues, 383.

5 Yosef Kaplan, From Christianity to Judaism: The Story of Isaac Orobio de Castro, translated from the Hebrew by Raphael Loewe (Oxford: The Littman Library of Jewish Civilization, 1989), 299.

6 Jacques Derrida, “The Law of Genre,” Critical Inquiry 7.1 (Autumn, 1980): 55-81. 


\section{Conventions of Illegality}

The genre of clandestine Hispano-Portuguese polemics against Christianity illustrated by Orobio should not have existed at all, according to the principles that ruled the legal conditions of Portuguese Jews in Protestant seaports. The reception of these uncommon immigrants aroused deep fears that "blasphemy" and overt expressions of disbelief were being brought into the Christian commonwealth. When the Hamburg Senate solicited opinions from three Lutheran faculties on the reception of Jews in 1611, the consulted theologians called the magistrate to prohibit the public exercise of the Jewish religion in order to avoid complicity in their blasphemous utterances against Christ. ${ }^{7}$ The contracts between the Senate and the Jews in 1612 and 1617 followed this recommendation and included the prohibition against offending the dominant religion "in words or deeds."

In Amsterdam, the eminent jurist Hugo Grotius drafted in 1615 a similar charter that threatened with heavy fines any possessor of books containing "words of blasphemy and defamation." "But the Amsterdam municipality solved the problem in a different way. It did not ratify a formal charter that would have called for the public prosecution of secret Jewish blasphemers. In 1616, it made a confidential agreement with the mahamad, i.e. the executive board of the local Sephardic community, holding said board responsible for restraining their fellow Jews from three transgressions that risked subverting existing power hierarchies: first, receiving proselytes; second, speaking or writing (spreken ofte schrijven) against the Christian faith; ${ }^{10}$ and third, having sexual relations with Christian women.

While Jewish proselytism remained exceptional, ${ }^{11}$ the two other transgressions, polemics and sex, were manifestly too pleasant to be avoided. Against the prohibition of their own communal authorities, Portuguese Jews of the seventeenth century produced an astonishing amount of texts that exalted their faith over that of the majority; Isaac Orobio was the champion of this literary effort. Under these circumstan-

7 Udo Arnoldi, Pro Iudaeis: Die Gutachten der hallischen Theologen im 18. Jahrhundert zu Fragen der Judentoleranz (Berlin: Institut Kirche und Judentum, 1993), 47-52.

8 Jutta Braden, Hamburger Judenpolitik im Zeitalter lutherischer Orthodoxie 1590-1710 (Hamburg: Christians, 2001), 111, 150; Aron di Leone Leoni and H. P. Salomon, "La Nation portugaise de Hambourg en 1617 d'après un document retrouvé," in Mémorial I.-S. Révah: Études sur le marranisme, l'hétérodoxie juive et Spinoza, edited by Henry Méchoulan and Gérard Nahon (Paris et Louvain: Peeters, 2001): 263-293, see 265.

9 Jaap Meijer, "Hugo Grotius’ Remonstrantie,” Jewish Social Studies 17.2 (1955): 91-104, here 100. 10 Arend H. Huussen Jr., "The Legal Position of Sephardi Jews in Holland, circa 1600," in Dutch Jewish History, vol. 3, edited by Jozeph Michman (Assen: Van Gorcum, 1993): 19-41; H. P. Salomon, Portrait of a New Christian: Fernão Álvares Melo (1569-1632) (Paris: Gulbenkian, 1982), 136.

11 Still, 108 converts to Judaism are documented in Dutch burial records of the seventeenth century, according to Alexander van der Haven, "Judeo-Christianity and Conversion to Judaism in the Seventeenth-Century Dutch Republic," lecture at the $17^{\text {th }}$ World Congress of Jewish Studies, Jerusalem, August 8, 2017. 
ces, anti-Christian writing was not an expression of self-indulgent orthodoxy but a daring venture that exposed its author to incalculable risk. In 1677, after the Calvinist synod of Dordrecht decided to promote "friendly conversations" with learned Jews, the Amsterdam Jewish community board tried to keep its members from any participation in such discussions, fearing they would stir up hate against the Jewish community in the Netherlands and might jeopardise its very existence. ${ }^{12}$ How suspicious the Jewish community authorities were in this respect is shown by Orobio when in 1665, he authored a manuscript against the esoteric thought of the medieval Franciscan friar Raymundus Lull. Since the Jewish community board would not give him the permission to have this text printed in Amsterdam, he sent it to Antwerp, where the Jesuits appreciated it-even the Society of Jesus had greater sympathy for Jewish polemics than the mahamad! ${ }^{13}$

This cautious self-censorship contributed to the distinct development of a specific genre in early modern book history. Hispano-Portuguese texts attacking Christian dogma needed to be copied by hand; they had to be bound in separate volumes, hidden in private homes, circulated confidentially as a separate body of literary production, and consumed under peculiar circumstances. We know from inscriptions on the coverleaves how these books were produced and circulated. Possessors would lend them to other community members and let the borrower make a copy for themselves, so that the tasks of scribe and reader merged in one person. When reading the note by which a redactor introduced his copy of a collection of Montalto's works: “in case you find any errors in my writing, dear reader and friend, I hope that you will judiciously correct them when you copy this book,"14 one is reminded of today's Internet communities whose members are simultaneously producers and consumers of their texts. At one point in his Divine Warnings, Orobio cuts short a prolific argument due to his compassion for his readers, who had to be scribes at the same time: "this would need a big volume, and since it cannot be printed, it would be extremely laborious to make copies of it by the pen." ${ }^{15}$ A clandestine writer of 1725, Abraham Gómez Silveyra (1656-1741), alluded jokingly to the scribal chores his audience had to take upon themselves: "Look, I would desire that these my manuscript books were imprinted in the heart of the readers, so that whoever wants to possess them would not have to take the pains of copying them."16 On the last page of an-

12 Quoted by Kaplan, From Christianity to Judaism, 273: "pois são tão perniciosas e danosas a nossa conservação fazendonos odiar por ellas das gentes adonde abitamos.”

13 Meijer, "Remonstratie," 100; Kaplan, From Christianity to Judaism, 186-187.

14 Ets Haim ms. 48 B 3, preface: "Si achareis algums erros no meu escrever, espero, am ${ }^{\circ}$ lector, os emmendaras con teu bon discurso em copiar este livro."

15 Orobio, Prevenciones divinas, part II, ch. 4, see Ets Haim ms. 48 D 6, fol. 125r, quoted by Kaplan, From Christianity to Judaism, 245: “... lo contrario ped[ir]ía un grande volumen, que no pudiendo ser impreso, sería muy diffisil reduzirlo a copias por la pluma.”

16 Ets Haim ms. 48 A 22, fol. 1r: "Mira como estos mis libros Manuscritos, los deseo en el corazón de los lectores impresos, para que no se moleste en trasladar quien los quisiere tener." 
other volume of Montalto's works, there is a note that shows how the text circulated in the Dutch Antilles: "The owner of this book herewith makes the vow that he will never lend it to any kind of person who will not first give him a sufficient pawn for the book. Curaçao, on 1 April, 1753. This book belongs to Ishac Mendes de Solla and was written by Mr. Joseph Vas da Costa." ${ }^{\text {"17 }}$ Mendes de Solla was wealthy enough to have his copy produced by a hired scribe. Interestingly, his bogeyman was not the Christian zealot who would denounce the blasphemous book, but rather the Jewish borrower who would forget to return it to him.

Donors, scribes, owners, and borrowers formed a dense medieval-style network of manuscript production and consumption. Anthony Collins, in his Discourse on the Grounds and Reasons of the Christian Religion of 1724, knew to report that Jewish antiChristian treatises "go about Europe in manuscript," but he added that this borrowing and copying community was almost impenetrable for Christians. Concerning Rabbi Saul Levi Mortera's Providencia, he writes:

[T]his work of his is esteem'd by the Jews to be the shrewdest book they have against Christianity. They are forbid, under pain of excommunication, to lend it to any Christian, for fear of drawing a storm upon themselves for producing such strong objections against the Christian Religion. Wherefore no copies are to be procur'd of it but by the greatest accidents. ${ }^{18}$

The manuscripts circulated almost exclusively in a Jewish readership, but the high prices that Christians were ready to pay for them made them lucrative merchandise, and it seems that Amsterdam Jews did sometimes copy certain texts for the Gentile market. ${ }^{19}$ This clandestine library thus exerted an enduring fascination on various groups: on early modern Jewish readers, on contemporary Protestants who feared blasphemy, on free-thinkers of the radical enlightenment, on nineteenth-century bibliophiles, and, finally, on historians like me, who started some thirty years ago to track down these texts in various libraries.

\section{History and Inventory of the Genre}

In 1988, Miguel Benítez published an inventory of 130 clandestine French manuscript works against Christianity that circulated, some of them in a host of copies, during

17 Ets Haim ms. 48 D 27, end: "O dono deste libro distomou com juramento de não emprestallo a ninhum genero de pessoa sem que primeiro [crossed-out passage] darlhe um penhor suficiente por seu livro. Curaçao a 1. Abril anno 1753. Este livro he de Ishac Mendes de Solla. Escripto por o Sr. Josseph Vas da Costa.”

18 Anthony Collins, Discourse on the Grounds and Reasons of the Christian Religion (London: n. p., 1724), 83-84.

19 Richard H. Popkin, “Jacques Basnage’s Histoire des Juifs and the Bibliotheca Sarraziana,” Studia Rosenthaliana 22 (1987): 154-162. 
the early Enlightenment period. ${ }^{20}$ The same task is still to be accomplished for the Sephardic clandestiniana in European languages. According to provisional results of my own research, there are today approximately 200 handwritten volumes totalling about seventy-five different texts by three dozen authors. More than three-quarters of the total are written in the Spanish language, most of the others in Portuguese, besides some exceptional pieces in Latin, Italian and Dutch. Geographically, nearly all of the texts were composed and copied in the Netherlands, with only a few items from Italy, France, Hamburg, or the Dutch possessions overseas. Today, the largest collection is that of Ets Haim in Amsterdam, with 64 volumes, ${ }^{21}$ and the second largest is at the State and University Library in Hamburg, with 17 volumes. ${ }^{22}$ There are five libraries that possess between ten and fifteen volumes each, namely the Royal Library of The Hague (14), the British Library in London and the Bodleian Library in Oxford (13 each), the University Library of Amsterdam (12), and the Jewish Theological Seminary in New York (10). Smaller collections, many of them private, exist all over the world.

Chronologically, the first extant anti-Christian text written by a Portuguese Jew is the anonymous Marrakesh Dialogues of $1583^{23}$ and the last is Abraham Gómez Silveyra's Silveyradas, the seventh and last volume of which was composed in $1738 .^{24}$ We possess, however, little direct testimony from the first decades of the genre. The oldest dated manuscript known to me, now in possession of the Library Company of Philadelphia, is from $1652 .{ }^{25}$ Dated colophons became more frequent when Iehuda Machabeu, a professional scribe, produced a series of copies in 1662. The most recent dated volume is from $1759 .^{26}$

Most of the extant copies were produced during the years $1680-1715$, that is, the years of the "crisis of European consciousness," in the terms of Paul Hazard, ${ }^{27}$ or the

20 Miguel Benítez, "Matériaux pour un inventaire des manuscrits philosophiques clandestins des XVII ${ }^{\mathrm{e}}$ et XVIII ${ }^{\mathrm{e}}$ siècles," Rivista di storia della Filosofia 43 (1988), 501-531. See also Benítez, La face cachée des Lumières: Recherches sur les manuscrits clandestins de l'âge classique (Paris: Universitas, 1996).

21 Leo Fuks and Rena Fuks-Mansfeld, Hebrew and Judaic Manuscripts in Amsterdam Public Collections, vol. II: Catalogue of the Manuscripts of Ets Haim/Livraria Montezinos, Sephardic Community of Amsterdam (Leiden: Brill, 1975), 91-132; Raphael Weiser and Yosef Kaplan, Treasures from the Library Ets Haim-Livraria Montezinos of the "Portuguese Israëlitisch Seminarium Ets Haim," Amsterdam, Jerusalem: Jewish National and University Library, 1980, 76-81.

22 Moritz Steinschneider, Catalog der hebräischen Handschriften in der Staatsbibliothek Hamburg (Hamburg: Otto Meisner, 1878), 164-171; Ernst Roth and Hans Striedl, Hebräische Handschriften in Deutschland, vol. III (Wiesbaden: n.p., 1984), 326-331.

23 On the dating see Wilke, Marrakesh Dialogues, 29-32, 91-97.

24 Ets Haim ms. 48 B 18, fol. 282r, the last folio of the volume, quotes the "Gazeta del Haya Lunes 30 de Junio 1738."

25 Wilke, Marrakesh Dialogues, 155-157.

26 Ets Haim ms. 49 A 10.

27 Paul Hazard, La Crise de la conscience européenne 1680-1715 (Paris: Boivin, 1934). 
"radical enlightenment," in the terms of Margaret Jacob and Jonathan Israel. ${ }^{28}$ As we have already seen, Jewish writing against Christianity was interconnected in various ways with the critical interests of the time. The two clandestine literatures, one produced by Gentiles in French or Latin, the other by Jews in Iberian languages, present not only a parallel chronology, but also parallel features. Jewish anti-Christian writing, however, differs from its non-Jewish counterpart insofar as it remains concerned with authorship and literary glory, whereas Gentile free-thinkers consumed their disbelieving discourse in a host of anonymous or pseudonymous pamphlets without developing the same trend towards canonicity.

If we review the Jewish authors who had the most lasting success (counting the extant manuscript volumes of their works), four of them clearly stand out. The most popular writer was our Isaac Orobio, of whom there are seventy-seven extant volumes (sixty of which are in Spanish or Portuguese ${ }^{29}$ and seventeen of which are in French translations). Almost equal to him in literary success was Saul Levi Mortera, whose polemical works are conserved in sixty-one volumes. ${ }^{30}$ The third place is due to Abraham Gómez Silveyra, whose writings are attested now in twenty-five folio volumes. With Elijah Montalto, author of eighteen extant volumes, ${ }^{31}$ these writers form a canonical quartet, all based in Amsterdam (except Montalto, who never visited the city but was buried there).

Various other works enjoyed a slightly more limited circulation; in these cases, however, the personality of the author was not as clearly present in the minds of the readers. An example of this category is the Marrakesh Dialogues, which were transmitted in ten copies, all of them anonymous. ${ }^{32}$ The author decided not to entrust his name to the manuscript ${ }^{33}$ and only by research into the text's historical origins did I hypothetically identify him as one Estêvão Dias from Tavira. ${ }^{34}$ A treatise transmitted in eight manuscripts under various titles had the opposite fate: signed by Isaac Naar (1631- after 1686) in its earlier copies, later copyists anonymised this text. $^{35}$ A curious work titled Fortress of Judaism (Fortalezza dell'ebraismo), written

28 Margaret C. Jacob, The Radical Enlightenment: Pantheists, Freemasons and Republicans (London: George Allen \& Unwin, 1981); Jonathan I. Israel, Radical Enlightenment: Philosophy and the Making of Modernity 1650-1750. Oxford: Oxford University Press, 2002.

29 See the catalogue by Kaplan, From Christianity to Judaism, 431-440.

30 See the catalogue by H.P. Salomon, Saul Levi Mortera en zijn "Traktaat betreffende de Waarheid van de Wet van Mozes, "eigenhandig geschreven in de Portugese taal te Amsterdam 1659-1660. Inleiding, transcriptie en aantekeningen (Braga: Barbosa \& Xavier, 1988), xvi-xx.

31 Peter T. van Rooden, “A Dutch Translation of Elias Montalto’s Tratado sobre o princípio do Capítulo 53 de Jesaias. Text, Introduction and Commentary,” Lias 16 (1989): 189-238.

32 Wilke, The Marrakesh Dialogues, 153-165.

33 Wilke, The Marrakesh Dialogues, 204.

34 Wilke, The Marrakesh Dialogues, 46-58.

35 Carsten L. Wilke, "Midrashim from Bordeaux: A Theological Controversy inside the Portuguese Jewish Diaspora at the Time of Spinoza's Excommunication," European Journal of Jewish Studies 6.2 (2012): 207-247, here 214-215. 
in a strongly Hispanicised Italian by Abraham Guer de Cordoba, is known in seven manuscripts in the original language and three in a Hebrew translation. Here again, only recent research has shed light on the possible biography of the author, who may have been identical with Lorenzo Escudero, a proselyte of morisco ancestry who had been an actor on the Spanish stage. ${ }^{36}$ Rabbi Isaac Athias' translation of a Hebrew work, Strengthening of the Faith, by Isaac Troki, a Lithuanian Karaite scholar about whom the translator himself knew very little, ${ }^{37}$ and a dialogue set in Livorno, Danielillo, or Answers to the Christians, whose author remains unknown to this day, exist in four copies. ${ }^{38}$

A third group of texts are preserved only in single copies and apparently failed to reach a larger audience. Some of them were authored by well-known scholars such as Rabbi Mosseh Refael d'Aguilar, whose polemical writings are, however, only extant in his personal papers. ${ }^{39}$ Finally, we know the titles of about ten works of which no copy survives. This loss is regrettable for the voluminous Propugnaculum Judaismi that the jurist Judah Lumbroso alias António Dias Pinto wrote in Latin against Hugo Grotius' Truth of the Christian Religion, ${ }^{40}$ and even more so for the Religious Theologian Opposing the Political Theologian (Theologo religioso contra o Theologo politico) that Jacob de Andrade Velosinho composed in Portuguese against Spinoza's Theological-Political Treatise. ${ }^{41}$

Although the reception of anti-Christian literature among the Sephardim covered a large range of literary products, readers' attention concentrated on the four most reputed authors-Montalto, Mortera, Orobio and Gómez Silveyra, in chronological order-whose peculiar history and style made them the object of a celebration of genius not much different from the cult of vernacular literary classics during the baroque age. Daniel de Barrios stated that Montalto "wrote so much in defense of the Most Holy Law that one could print not unimportant volumes from it; but whoever possesses them in manuscript appreciates them more than precious stones." ${ }^{2}$ In 1670, an anonymous editor assembled a manuscript edition of Montalto's collected

36 A. Stanley Dreyfus, Tseriah Bet-El: Marco Luzzatto's Hebrew Translation of the Spanish Work Fortaleza del judaismo y confusión del estraño, unpublished thesis, Hebrew Union College 1949; Yosef Kaplan, "Kelitatam shel gerim ba-kehillah ha-portugezit be-Amsterdam ba-me'ah ha-17: Parashat Lorentso Eskudero," World Congress of Jewish Studies 7, no. 4 (1981): 89-99.

37 See the translator's preface in British Library, Harley 4634.

38 Wilke, The Marrakesh Dialogues, 166-168.

39 Yosef Kaplan, "Mekomo shel ha-Rav Mosheh Refael d'Agilar bemasekhet kesharaw im pelitei Sefarad u-Portugal ba-me'ah ha-17," World Congress of Jewish Studies 6 (1976), vol. 2, 95-106.

40 Meyer Kayserling, "Une histoire de la littérature juive de Daniel Levi de Barrios," Revue des études juives 18 (1889): 276-289.

41 Diogo Barbosa Machado, Bibliotheca lusitana historica, critica, e cronologica (Lisbon: Officina de Antonio, vol. 2, Isidoro da Fonseca, 1741), 468-469.

42 Kayserling, "Une histoire de la littérature juive de Daniel Levi de Barrios." 
writings from three different clandestine texts in their original Portuguese. ${ }^{43}$ One copy of this edition, now owned by the Hamburg State Library, imitates the layout of a printed edition. ${ }^{44}$ A few years later, in 1679, Joseph and Semuel Israel Pereira brought together the three major anti-Christian works of Isaac Orobio into a manuscript edition that became fundamental ${ }^{45}$ and that is still documented in fourteen copies. Both of these "collected works" editions contain preliminary poems praising the author, as was customary in printed books at the time.

From 1704, Abraham Machorro produced a more comprehensive edition of Orobio's writings; a later edition by Daniel Lopes Quiros, made in 1712, undertakes an effort to bring together all the known texts by the author. Both editions are preserved in various manuscript copies, some of them containing decorative drawings and ornaments, not to mention the sumptuous leather binding and gilding. Two volumes even boast fanciful portraits of Orobio in watercolour paintings that imitate engravings. ${ }^{46}$ Around 1725, Abraham Gómez Silveyra organised a seven-volume edition of his works under the title Silveyradas, trying to become a classic of the clandestine genre by his own efforts. He was successful insofar as he inspired readers to produce impressively calligraphed copies of the entire multi-volume cycle. One deliciously decorated specimen at Yeshiva University has recently been entirely digitised. ${ }^{47}$ The material layout of the books itself bespeaks an attitude of admiration and veneration towards the authors who sometimes, as in Orobio's case, underwent a canonisation process during their lifetime.

\section{Internal Purposes}

As anti-Christian polemics seem to have been a relatively popular genre among the Sephardim of the late seventeenth century, we should ask for the cultural motivation, the social context, and the intellectual energy that fuelled it. We cannot just satisfy ourselves with the reference to some dogmatic fury that had allegedly seized Jews in general or Orobio in particular. What, then, motivated dozens of authors and readers to busy themselves with writing, manually copying and reading long, clandestine texts that discussed exegetic detail in militant language?

43 Ets Haim ms. 49 A 1, title: Obras do Doctor Eliau Montalto em Amsterdam no Anno 1670. Copiado na corte de Haya no Anno 1740.

44 Hamburg, Staatsbibliothek, Levy 20, Spanish title: Trattado sobre el cap 53 de Ezayas echo por el Dr Montalto en Amsterdam el el ano 1670.

45 British Library, Harley 3430. The Pereira edition starts with the Prevenciones, follows the Respuesta a un predicante francés, and ends with the Epístola invectiva.

46 Hamburg, Staatsbibliothek, heb. 85a, written by Jacob Guedella in 1713, is bound with a preliminary portrait with a cut-out name frame and the artist's signature “Jacobus Groenwolt, 1727." See Kaplan, From Christianity to Judaism, 386.

47 Yeshiva University, ms. 1374; http://digital.library.yu.edu/yeshiva-university-libraries-manuscripts 
Yosef Kaplan gave three answers to these questions. ${ }^{48}$ The founders of the Portuguese communities had suffered under the Inquisition and therefore developed an obsessive hostility towards their former religion. They had lived in an atmosphere of secrecy for generations and were in need of defining clear doctrinal boundaries. Finally, once they had reached the free intellectual climate of the Netherlands, religious pluralism created doctrinal challenges inside and outside the Jewish community that asked for a defence of one's own religious persuasions. Herman Salomon, in contrast, supposed that Mortera also had an agenda of outreach; he directed himself directly to Christian dissidents who had rejected the dogma of the Trinity and whom he hoped to induce to an observance of the Noahite Laws according to rabbinic Judaism. ${ }^{49}$ Considering the simultaneous presence of internal and external addressees in these clandestine works, let us now inquire whether producers and consumers were part of an actual cross-religious intellectual dialogue or whether their controversial activity was merely a pretext for an inward-looking stabilisation of their own religious culture.

The prefaces of the clandestine works strongly support the latter alternative. They never address a Christian adversary directly but show that the author's imaginary audience is among Jews, or at least among New Christian seekers for truth. Estêvão Dias, the author of the Marrakesh Dialogues, writes in his preface: "This is a pleasant reading for all those who strive for learning, knowledge of the truth and the salvation of their souls. May Our Lord show them the truth!" 50 Isaac Athias titles his translation of the Hebrew Hizzuk Emunah: "Fortification of the faith . . . the pillar that fortifies the afflicted hearts of the house of Israel in its exile, showing them the eternal salvation for which they hope, as well as the darkness in which their adversaries live." ${ }^{51}$ What these texts intended to achieve was not a successful confrontation with Christianity. Rather, these texts sought to bolster the reader's self-esteem through setting in motion a mental process that was called by their authors the "fortification of the faith," hizzuk emunah in Troki's Hebrew. Mortera declares at the end of his list of 179 objections against the New Testament:

I have undertaken all this work as a warning for those of my nation who were forced to abandon their ancestral law, which is confessed as divine in the entire world, and who confess the Gospel under the cruel scepter of the Inquisition, so that they may better know how to distinguish between the truth and light they have abandoned and the things they were made to confess by force. $^{52}$

48 Kaplan, From Christianity to Judaism, 362.

49 Salomon, Mortera, lxxxiv-lxxxv.

50 Wilke, The Marrakesh Dialogues, 203.

51 Ets Haim ms. 48 D 5, title page; reproduction in Weiser and Kaplan, Treasures, 77.

52 Ets Haim ms. 48 C 20, fol. 43v: "todo este trabajo emprendí para advertimiento de aquellos que de mi nación fueron forzados a dejar la ley de sus padres confesada por divina por todo el mundo y profesar la del Evangelio debajo la cruel vara de la Inquisición, para que sepan mejor distingüir entre la verdad y luz que dejaron a lo que le hicieron recibir forzadamente.” 
The author of the Fortress of Judaism writes quite similarly: "I have only written this in order to give consolation to our brethren, the dispersed anussim [forced apostates], who in many occasions must hear the learned and sophistical reasons of our adversaries, so that they may open their eyes, which the learned men of Edom try to obfuscate with their illusions." ${ }^{53}$ Orobio no less explicitly justifies the aim he pursues in one of his texts that was apparently written for readers in Antwerp or France:

These chapters concerning Isaiah 53 have been written at the request of a number of individuals living outside Jewry, whom others strive to alienate from the fulfilment of the holy Law ... there are amongst them some who because of their own weakness flounder in confusion, and others, because of their ignorance, are deceived. Many there are who are moved by much good will and zeal for the holy Law who wish to get to know the true interpretation, for the sake of their own spiritual peace of mind and in order to have at their hand a rejoinder to their opponents. ${ }^{54}$

Melnick believed the polemicists' inflexible insistence on their religious truth to be a mark of "conservative" inadaption to Amsterdam's peaceful pluralistic society. ${ }^{55}$ It seems to me that the exact opposite is true. In an urban society where Portuguese Jews, or "port Jews" in general, did not have a language, costume, and folklore of their own, community difference was affirmed through doctrinal persuasions and symbolic self-fashioning, just as this was generally the case in the early modern trends towards confessionalisation. In the Netherlands, the polemics between Protestants and Catholics and between Gomarists and Arminians were inevitably handled as perpetual zero-sum conflicts in which sharply polemical mutual condemnations could coexist with peaceful quotidian relations and even cooperation in practical matters. ${ }^{56}$ In 1645 , Mortera similarly uttered his conviction that no confession of Jewish faith could remain irenic and whoever affirms Judaism must deny Christianity, but a Jew should only make his theological standpoint public in situations of legitimate defence and political opportunity.

If you think about what it means that someone confesses his Jewishness and that he observes the divine law in accordance with the precepts that are included in it, then you will also understand that he will consider everything that is not his way as being opposed to the truth that he confesses ... He is free of blame if he finds himself in the necessity to defend himself by revealing the flaws of his adversary; and though we will not proclaim this, since we do not want to offend

53 Parma, ms. Palat. 2336, fol. 183v: "solamente l'ho fatto per consolar a' nostri frattelli gli Anussim sparsi, che sono in più occasione per ascoltare studiate e sofistiche ragioni, contrarie delli contrarij e aprirli gli occhi, che gli savii d'Edom procuranno cerrar con suoi ilussioni." Cf. Obadia 1:8 KJV: "Shall I not in that day, saith the LORD, even destroy the wise men out of Edom, and understanding out of the mount of Esau?"

54 Ets Haim ms. 48 D 16, prologue, quoted by Kaplan, From Christianity to Judaism, 251.

55 Melnick, From Polemics to Apologetics, 23.

56 Freya Sierhuis, The Literature of the Arminian Controversy: Religion, Politics and the Stage in the Dutch Republic (Oxford: Oxford University Press, 2015), 20. 
those from whom we receive support and protection, our Sages were not obliged to observe similar arrangements, and it would be ignorant to accuse them of the crime of saying such things..$^{57}$

Whatever political protection the Dutch Republic offered to its various religious communities, Mortera likened the debates between them to a murderous sea battle of all against all with powder-laden warships threatening each other. ${ }^{58}$ Paradoxically, the clandestine anti-Christian polemics were in fact a sign of cultural integration into a Dutch society that followed the unwritten rules of nonviolent confessional competition.

\section{Constructed Adversaries}

There is a curious tension between the internal homiletic finality of polemical writings and the external cause that is always said to have provoked them. Most of our polemicists sincerely acknowledge their lack of Jewish training and authority and do not want to challenge the preeminence of rabbinical authorities in intellectual matters. In their texts they find a need to point to particularly vicious external attacks in order to justify why they engage in theological speculation. In the prologue to his Prevenciones, Orobio admits that it is not his "profession" to explain the Bible, but some Carmelite monks had presented to him a learned argument to which the presence of a high-ranking nobleman had obliged him to respond; some friends, presumably Jewish, then encouraged him to put down his answer in writing, a huge treatise being the result. ${ }^{59}$ Besides having awkward feelings about their interference into a department of rabbinical competence, our authors seem to be committed to an ideal of religious truce that could only be broken if it was transgressed by Christian adversaries. In a printed translation of Josephus' Contra Appion that he dedicated to Isaac Orobio in 1687, Joseph Semah Arias states this lofty ideal: "we observe our religion without slandering the others, unless the latter provoke us by offending ours.

57 Ets Haim ms. 49 B 3, fol. 136v-137r: "Tanto que se conçiderare que cossa es profesar el ser judío y que sigue la ley diuina conforme los perceptos contenidos en ella, luego se entenderq que todo lo que no fuere esto se deue jusgar por contrario de la verdad que prophessa [...] queda desobligado de algun cargo el que tiene neçesidad de defenderse con descubrir el defeto ageno, y aunque nosotros no diremos esto por no ofender a aquellos de quien reçibimos el benefiçio y amparro, todavia nuestros sabios, como no obligados assemegante correspondençia, es ignorançia acuzarlos de crimen en dizir aquello."

58 Salomon, Mortera, 3.

59 Orobio, Prevenciones divinas contra la vana idolatria de las gentes, edizione critica, con introduzione, note di commento e riassunti parafrasi in italiano a cura di Myriam Silvera, vol. 1 (Florence: L. S. Olschki, 2013), 14: "En ninguno de las partes en que he dividido [i.e. divisado?] los Sagrados Escritos presumo dar mi parecer o exposición alguna, porque no tengo principios de que deducirla, y es asumpto mui ageno de mi profesión, solo es mi entento por satisfacer al ruego de algunos amigos referir la repuesta que di a una persona de grande autoridad." 
If you are foolish and stupid [...] I will write against you, [...] and if you are virtuous [...], then I will write in your favour and in favour of all those who wish to approach the subject without interest, passion, or envy." 60

For generic reasons, any Portuguese-Jewish polemical text would present itself as an urgent defensive manoeuvre against a concrete Christian missionary attack. This fiction is upheld in most treatises, and Orobio, in particular, stresses the fact that all of his religious writings emerged in a polemical context against an opponent, and that this opponent had always been the provoking party: this was first the case of the Jewish deist Juan de Prado, who had sent position papers from Antwerp, then the Catholic mystic Alonso de Zepeda, then an unnamed Huguenot pastor, then the mentioned group of Carmelite monks, then the crypto-Spinozist Jan Bredenburg, and finally the Remonstrant theologian Philippus van Limborch. As we have seen, the relationship between the author and the offender often included a prestigious third party, the presence of which made it impossible to ignore the provocation. The author of the Marrakesh Dialogues thus evokes a triangular argument between an Augustine monk, the Portuguese ambassador, and himself; Montalto wrote against a Dominican friar in Venice who was protected by an unnamed gentleman. The same constellation still legitimises Orobio's Prevenciones; it is even maintained in the French adaptation Israël vengé.$^{61}$ Abraham Gómez Silveyra wrote all his many volumes against one 1699 book in which the Huguenot preacher Isaac Jacquelot challenged Jewish rabbis publicly. Gómez Silveyra, however, noted in 1725 that Jacquelot had died in Berlin several years earlier without ever knowing about the huge Jewish refutation against his book. Gómez Silveyra had never bothered to contact the pastor whom he had chosen as his primary adversary. ${ }^{62}$

One is reminded of Petrarch, who directed sonnets to his beloved Laura without caring about whether she read them or not, and even continued this practice long after her death. Sephardic polemics required the fantasy of the invasive monk or pastor just as Renaissance love poetry needed the literary fiction of a young lady in the flesh to whom the poet allegedly directed his literary effusions. It is thus understandable that authors sometimes chose to fight with Christian adversaries who were neither living nor present on the book market. In 1645 Mortera defended the Talmud against the long-forgotten Sixtus of Sienna, an apostate who in his Bibliotheca sancta of 1566 had censured forty-nine rabbinic propositions. Again, Mortera's work is os-

60 Respuesta de Josepho contra Apion Alexandrino, trad. Joseph Semah Arias (Amsterdam: David Tartas, 1687), preface: “observamos nuestra Religion sin calumniar las estrañas, sino quando nos provocan ultrajando la nuestra. Si eres necio y estupido [...] escrivo contra ti, [...]; y si eres virtuoso [...], escrivo para tí, y para los que desinteresadamente miran las cosas sin pasion, ò invidia.” 61 Orobio, Israël vengé, ou Exposition naturelle des prophéties hébraïques que les chrétiens appliquent à Jésus, leur prétendu Messie, traduit sur le manuscrit par Henriquez, edited by Baron d'Holbach. (London: n.p., 1770) 190.

62 Ets Haim ms. 48 B 17, fol. 131v: "Agora lei en la Gazeta hauia muerto my hombre Yshac Jacquelot, y lo senti mucho, que le queria escrevir, y lo deseava comunicar.” 
tensibly designed to thwart the attack of a Christian adversary, but in reality it seeks to relieve the doubts of fellow Jews. ${ }^{63}$ In the second part of his Prevenciones, Orobio refutes the Scrutinium Scripturarum of Santa María, a text written in 1434 that was out of print for almost a century. All these polemics of the Amsterdam Jews depended on the literary fiction of a Christian attack that needed to be thrown back, regardless of its actual threat.

Moreover, the Christian missionary was not always portrayed as he might actually exist in Dutch social reality but in a way that allowed the literary triumph over him to be most impressively staged. In the Danielillo dialogue, a young Italian Jewish boy wins out over several monks; in another text, Abraham Gómez Silveyra, a self-fashioned aggressive polemicist, confronts the learned pastor Jacquelot with only a Bible and his humour:

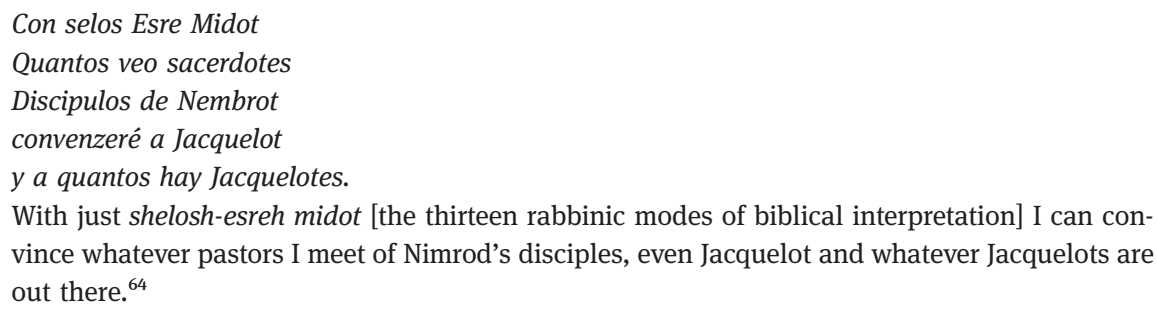

In spite of the theatrical aggressiveness of these texts, they are in reality more interested in a Jewish introspective than in actual controversy. What they deal with obliquely are the doubts that were common among their readership, especially among Jews who were exposed to Christian propaganda and secular culture. The fundamental task of Orobio and his fellow writers was not to make Judaism as such triumph over Christianity but to reconcile tradition with the critical thought that unsettled the Portuguese Jewish community inside its Dutch environment.

\section{Polemical Subgenres}

The need to evoke a concrete scenario featuring interreligious controversy may help us to understand the personalised character of the Jewish polemical genre and the peculiar function of Orobio and the other three literary glories inside it. Regarding these canonised Jewish polemicists, it should be noticed that all of them assumed the role of exemplary "New Jews" and cultural intermediaries. Each one in a different way was able to connect the Iberian background of their readers with the literary traditions inside as well as outside Judaism.

63 Salomon, Mortera, lxxii-lxxv.

64 Ets Haim ms. 48 B 17, fol. 236r. 
Let me classify these authors in three types: rabbis, doctors, and poets. Saul Levi Mortera was a community rabbi of the Amsterdam congregation Beth Yahacob and a bilingual writer fluent in Hebrew and Portuguese. An Ashkenazi educated in a Sephardic religious school of Venice, he left an oeuvre of Hebrew sermons ${ }^{65}$ and Portuguese anti-Christian texts that were translated into Spanish after his death.

Among the doctors, the clear role model was Montalto, a famed physician in Lisbon, Paris, and Florence, who chose the life of a ghetto Jew in Venice before being recalled with great honour by the French crown in spite of his apostasy. ${ }^{66}$ Bilingual in Latin and Portuguese, he used the first language for his medical work and the latter for religious polemics, which were later translated into Spanish. Orobio, a physician who grew up in Spain, repeatedly confesses his ignorance of Hebrew and his lack of training in rabbinic exegesis; he read Latin and had a command of literary Spanish, in which he wrote all of his texts, though he was presumably fluent in Portuguese as well. An even more hybrid intellectual personality was Isaac Naar, an academic physician who had also studied the Talmud in Rabbi Mortera's academy. As the first community rabbi with a university doctorate, he symbolises the cultural synthesis that polemical writing seems to have necessitated. Born in Hamburg, Naar expressed himself in Portuguese and also could read Latin and Hebrew.

Turning to the poets, the cultural background of Abraham Gómez Silveyra is still more complex. He grew up in Spain and wrote in a literary Spanish that was trained by the example of siglo de oro poetry. He then received a Hebrew education at an Amsterdam orphanage, though not to an extent that would have allowed him to use it actively. ${ }^{67}$ Later, Gómez Silveyra lived for a long time in Antwerp and became fluent in French, so that he had gained a triple competence in Hispanic, rabbinic, and Enlightenment culture.

All six of these polemicists were thus brokers between Jewish, Christian, classical, and modern learning on the one hand and their coreligionists' specific Iberian background on the other hand. The lay authors among them readily acknowledged their lack of rabbinic qualification but compensated for it by their prestigious training inside the early modern academic environment. In sum, the Jewish polemicists applied a high degree of intellectual specialisation when they communicated internal and even clandestine concerns not in their vernacular Portuguese but in the al-

65 Marc Saperstein, Exile in Amsterdam: Saul Levi Morteira's Sermons to a Congregation of "New Jews” (Cincinnati: Hebrew Union College Press, 2005).

66 See Orobio's praise of Montalto in I. S. Révah, Spinoza et le dr Juan de Prado (Paris and The Hague: Mouton \& Cie., 1959), 140.

67 Henry Méchoulan, “A propos de la liberté de conscience: remarques sur un manuscrit d'Abraham Gomes Silveyra,” in Nature, croyance, raison: Mélanges offerts à Sylvain Zac (Fontenay-aux-Roses: École Normale Supérieure, 1992): 25 -41; Shalom Rosenberg, and Alexander Even-Chen, "Coplas filosóficas de Abraham Gómez Silveyra,” Revue des études juives 153 (1994): 327-351; Kenneth Brown and Harm den Boer, El Barroco sefardí: La poesía de Abraham Gómez Silveira, estudio y edición (Kassel: Reichenberger, 2000). 
legedly more international Spanish language, and their followers created personality cults around them due to their particular literary grandeur.

Our clandestine classics thus became social and literary types representing specific cultural and intercultural profiles with their characteristic literary forms. Isaac Athias and Saul Levi Mortera, the rabbis who contributed to the polemical literature, use the medieval mode of polemical expression: they compiled inventories of exegetic arguments in the order of the biblical text. The doctors Montalto and Orobio wrote theological treatises with a coherent reasoning, dividing their works into chapters and utilising sophisticated rhetoric. For example, Orobio defends Judaism in his Invective Epistle in a rigidly systematic progression, proceeding in four steps from God to Scriptural revelation, the oral law and finally the recent legal customs and rabbinical decisions. ${ }^{68}$

Forms from vernacular literary tradition are frequently employed among the lay authors of polemics. The Marrakesh Dialogues, whose author was apparently a merchant, writes in the Renaissance fashion of the dialogue, a form that was imitated by several authors in the first half of the seventeenth century. ${ }^{69}$ Other laymen left prose narratives of their conversion stories, and gifted poets such as Antonio Enríquez Gómez and Abraham Gómez Silveyra expressed their anti-Christian argument in refined verse of the Spanish fashion. These laymen also use an abundant dose of humour, which is absent from the writings of the institutionalised scholars. Rabbis, doctors, and poets were three intellectual types of the Amsterdam community whose specific forms of polemicising were adapted to their cultural profile.

Theological content, social setting, and literary form are thus closely linked in the polemical genre. This observation might help forward the discussion of the question of literary innovation and originality that the historian has to ask when dealing with anti-Christian writings, a markedly anachronistic chapter of manuscript circulation in the early modern history of the book. I have been exchanging views with Professor Daniel Lasker on the point, who in an article published in 2005 observed that the early modern Jewish argument with Christianity remained basically tied to medieval conventions. ${ }^{70}$ I agree with Lasker that the varied exegetical, philosophical, and ethical reasonings of the anti-Christian texts have their precedents in the Middle Ages. However, in the writings of Orobio and his contemporaries, we find typically medieval exegetic thoughts put to work in European languages and new literary

68 Natalia Muchnik, Une vie marrane: Les pérégrinations de Juan de Prado dans l'Europe du XVII siècle, Paris, Honoré Champion, 2005, 449.

69 Yosef Kaplan, "R. Shaul Levi Mortera wehibburo 'Te'anot wehassagot neged ha-dat ha-notsrit," Mehqarim at toledot yahadut Holand 1 (1975), 9-31.

70 Daniel J. Lasker, "Jewish Anti-Christian Polemics in the Early Modern Period: Change or Continuity?" in Tradition, Heterodoxy, and Religious Culture: Judaism and Christianity in the Early Modern Period, edited by Chanita Goodblatt and Howard Kreisel (Beer-Sheva: Ben-Gurion University of the Negev Press, 2006): 469 -488; Wilke, The Marrakesh Dialogues, 4-5; Lasker, review essay in Journal of Jewish Studies, 67.2 (2016), 431. 
frameworks for a purpose that transcends the actual needs of propagandistic self-defence. The kind of answer we might give to the originality question hinges largely on the more or less rigid distinction that we make between content, form, and purpose.

Medieval Jewish polemics against Christianity served a practical aim, they suggested answers to Jews who confronted Christian proselytising. There was no lack of such situations in the early modern period either, ${ }^{71}$ but they do not seem to be the primary motivation for our polemicists, who were more interested in engaging in virtual debates with half-fictional adversaries. In some cases, such as Isaac Naar's debate with the Bordeaux canon Jérôme Lopes in the mid-seventeenth century, or Orobio's controversy with his former friend Juan de Prado, the debate is triggered by an adversary from inside the New Christian group who may be either a Catholic believer or a free-thinker. But, as a rule, the texts that affirm Judaism against monks or pastors are no less directed at internal doubts than those that attack freethought in the Nation's own ranks.

\section{Situational Scepticism}

I wish to conclude with the observation that in the seventeenth century, the distinction between confessional exclusivism on the one hand and a tolerant communicative rationality on the other hand was to a large extent situational. Religious propositions are not orthodox or subversive per se; their meaning needs to be understood in the social function they receive in a changing cultural context. There is first the choice of the audience and the generic framework that determines the more irenic or controversial nature of religious thought; second, there is the individual use of this genre made by an author in accordance with his specific training and the intellectual leadership role that he could fulfil within a Jewish community marked by intercultural transfers and boundary-crossings. Third, we can suspect that even during the quarter century of Orobio's literary production, the direction of his argument changed constantly, successively singling out free-thinkers, Church dogmatists, Spinozists, and rationalist Protestants as the most threatening targets of his writing. Orobio and the entire Sephardic genre against Christianity reacted to historical change in a far more nuanced way that the narrative leading from polemics to tolerance might suggest. Finally, the meaning of Jewish anti-Christian criticism changes again completely with its adoption by non-Jews. When Orobio's commentary on Isaiah 53 became, in French translation, the free-think-

71 Rena Fuks-Mansfeld, "Une rencontre en exil: Huguenots et juifs dans la République néerlandaise, 1685-1715," in Conflits politiques, controverses religieuses: Essais d'histoire européenne aux XVI -XVIII ${ }^{e}$ siècles, edited by Ouzi Elyada and Jacques Le Brun (Paris: Editions de l'Ecole des Hautes Etudes en Sciences Sociales, 2002), 59-76; Christiane Berkvens-Stevelinck, "En relatif dialogue: Juifs et remontrants à Amsterdam au dix-septième siècle," in L'antisémtisme éclairé: Inclusion et exclusion depuis l'époque des Lumières jusqu'à l'affaire Dreyfus, edited by Ilana Y. Zinguer and Sam W. Bloom (Leiden: Brill, 2003): 31-41. 
ers' treatise La divinité de Jésus-Christ détruite, his rewritten Jewish argument had acquired a far more subversive force.

The rise and impact of Judeo-Portuguese polemical literature is particularly intriguing in a long-term perspective. Texts that had been composed in the seventeenth century with the intention of proving the exclusive certainty of one's own religion, dissipating all doubts, and exploding rival conceptions of truth, would be used in the eighteenth century in order to promote a pluralism and rivalry of doctrinal systems that needed to be handled with the instruments of sceptical epoché, which refers to the trifold consideration that the contradicting claims between worldviews cannot be fought out to the end, that sustained disagreement is productive, and that peace through mutual toleration and recognition is preferable to a struggle for doctrinal purity. ${ }^{72}$ The social and cultural impact of a determined theological argument did not change only in the shift from the middle ages toward the early modern period: Jewish thought also vividly reacted to the steps that would lead from the cultural world of the Renaissance to that of the Enlightenment, from scepticism to dogmatism and back.

\section{Works Cited}

Amsterdam, Ets Haim, ms. 48 A 22.

Amsterdam, Ets Haim, ms. 48 B 3.

Amsterdam, Ets Haim, ms. 48 B 17.

Amsterdam, Ets Haim, ms. 48 B 18.

Amsterdam, Ets Haim, ms. 48 C 20.

Amsterdam, Ets Haim, ms. 48 D 5.

Amsterdam, Ets Haim, ms. 48 D 6.

Amsterdam, Ets Haim, ms. 48 D 16.

Amsterdam, Ets Haim, ms. 48 D 27.

Amsterdam, Ets Haim, ms. 49 A 1

Amsterdam, Ets Haim, ms. 49 A 10.

Amsterdam, Ets Haim, ms. 49 B 3

Hamburg, Staatsbibliothek, heb. 85a.

Hamburg, Staatsbibliothek, Levy 20.

London, British Library, Harley 3430.

New York, Yeshiva University, ms. 1374.

Parma, ms. Palatina 2336.

Arnoldi, Udo. Pro Iudaeis: Die Gutachten der hallischen Theologen im 18. Jahrhundert zu Fragen der Judentoleranz. Berlin: Institut Kirche und Judentum, 1993.

Benítez, Miguel. "Matériaux pour un inventaire des manuscrits philosophiques clandestins des XVII ${ }^{\mathrm{e}}$ et XVIII ${ }^{\mathrm{e}}$ siècles," Rivista di storia della Filosofia 43 (1988): 501-531.

Benítez, Miguel. La face cachée des Lumières: Recherches sur les manuscrits clandestins de l'âge classique. Paris: Universitas, 1996.

72 Benjamin J. Kaplan, Divided by Faith: Religious Conflict and the Practice of Toleration in Early Modern Europe (Cambridge MA: Harvard University Press, 2007). 
Berkvens-Stevelinck, Christiane. "En relatif dialogue: Juifs et remontrants à Amsterdam au dix-septième siècle." In L'antisémtisme éclairé: Inclusion et exclusion depuis l'époque des Lumières jusqu'à l'affaire Dreyfus, edited by Ilana Y. Zinguer and Sam W. Bloom, 31-41. Leiden: Brill, 2003.

Braden, Jutta. Hamburger Judenpolitik im Zeitalter lutherischer Orthodoxie 1590-1710. Hamburg: Christians, 2001.

Brown, Kenneth, and Harm den Boer. El Barroco sefardí: La poesía de Abraham Gómez Silveira, estudio y edición. Kassel: Reichenberger, 2000.

Collins, Anthony. Discourse on the Grounds and Reasons of the Christian Religion. London: n. p., 1724.

Derrida, Jacques. "The Law of Genre," Critical Inquiry 7.1 (Autumn, 1980): 55-81.

Dreyfus, A. Stanley. Tseriah Bet-El: Marco Luzzatto's Hebrew Translation of the Spanish Work Fortaleza del judaismo y confusión del estraño, unpublished thesis, Hebrew Union College, 1949.

Fuks, Leo, and Rena Fuks-Mansfeld, Hebrew and Judaic Manuscripts in Amsterdam Public Collections, vol. II: Catalogue of the Manuscripts of Ets Haim/Livraria Montezinos, Sephardic Community of Amsterdam. Leiden: Brill, 1975.

Fuks-Mansfeld, Rena. “Une rencontre en exil: Huguenots et juifs dans la République néerlandaise, 1685-1715." In Conflits politiques, controverses religieuses: Essais d'histoire européenne aux $X V I^{e}-X V I I I^{e}$ siècles, edited by Ouzi Elyada and Jacques Le Brun, 59-76. Paris: Editions de l'Ecole des Hautes Etudes en Sciences Sociales, 2002.

Gomes, Jesué Pinharanda. "Messianologia e integralismo sionista: Menassé ben Israel e Oróbio de Castro." In História do pensamento filosófico português, Vol. II: Renascimento e Contra-Reforma, edited by Pedro Calafate, 262-271. Lisbon: Caminho, 2001.

Hazard, Paul. La Crise de la conscience européenne 1680-1715. Paris: Boivin, 1934.

Huussen, Arend H., Jr. "The Legal Position of Sephardi Jews in Holland, circa 1600." In Dutch Jewish History, vol. 3, edited by Jozeph Michman, 19-41. Assen: Van Gorcum, 1993.

Israel, Jonathan I. Radical Enlightenment: Philosophy and the Making of Modernity 1650-1750. Oxford: Oxford University Press, 2002.

Jacob, Margaret C. The Radical Enlightenment: Pantheists, Freemasons and Republicans. London: George Allen \& Unwin, 1981.

Josephus, Respuesta de Josepho contra Apion Alexandrino, trad. Joseph Semah Arias. Amsterdam: David Tartas, 1687.

Kaplan, Benjamin J. Divided by Faith: Religious Conflict and the Practice of Toleration in Early Modern Europe. Cambridge MA: Harvard University Press, 2007.

Kaplan, Yosef. "R. Shaul Levi Mortera wehibburo 'Ṭe’anot wehassagot neged ha-dat ha-notsrit," Mehqarim at toledot yahadut Holand 1 (1975): 9-31.

Kaplan, Yosef. "Mekomo shel ha-Rav Mosheh Refael d'Agilar bemasekhet kesharaw im pelitei Sefarad u-Portugal ba-me'ah ha-17," World Congress of Jewish Studies 6, no. 2 (1976): 95-106.

Kaplan, Yosef. "Kelitatam shel gerim ba-kehillah ha-portugezit be-Amsterdam ba-me'ah ha-17: Parashat Lorentso Eskudero." World Congress of Jewish Studies 7, no. 4 (1981): 89-99.

Kaplan, Yosef. From Christianity to Judaism: The Story of Isaac Orobio de Castro, translated from the Hebrew by Raphael Loewe. Oxford: The Littman Library of Jewish Civilization, 1989.

Lasker, Daniel J. "Jewish Anti-Christian Polemics in the Early Modern Period: Change or Continuity?" In Tradition, Heterodoxy, and Religious Culture; Judaism and Christianity in the Early Modern Period, edited by Chanita Goodblatt and Howard Kreisel, 469-488. Beer-Sheva: Ben-Gurion University of the Negev Press, 2006.

Lasker, Daniel J. Review essay. Journal of Jewish Studies, 67, no. 2 (2016): 431.

Leoni, Aron di Leone, and H. P. Salomon, "La Nation portugaise de Hambourg en 1617 d'après un document retrouvé." In Mémorial I.-S. Révah: Études sur le marranisme, l'hétérodoxie juive et 
Spinoza, edited by Henry Méchoulan and Gérard Nahon, 263-293. Paris et Louvain: Peeters, 2001.

Machado, Diogo Barbosa. Bibliotheca lusitana historica, critica, e cronologica, 2 vol. Lisbon: Officina de Antonio Isidoro da Fonseca, 1741.

Méchoulan, Henry. "A propos de la liberté de conscience: remarques sur un manuscrit d'Abraham Gomes Silveyra." In Nature, croyance, raison: Mélanges offerts à Sylvain Zac, 25-41. Fontenay-aux-Roses: École Normale Supérieure, 1992.

Meijer, Jaap. “Hugo Grotius’ Remonstratie.” Jewish Social Studies 17.2 (1955): 91-104.

Melnick, Ralph. From Polemics to Apologetics: Jewish-Christian Rapprochement in Seventeenth-Century Amsterdam. Assen: Van Gorcum, 1981.

Muchnik, Natalia. Une vie marrane: Les pérégrinations de Juan de Prado dans l'Europe du XVII siècle. Paris, Honoré Champion, 2005.

Orobio de Castro, Isaac. Israël vengé, ou Exposition naturelle des prophéties hébraïques que les chrétiens appliquent à Jésus, leur prétendu Messie, traduit sur le manuscrit par Henriquez. Edited by Baron d'Holbach. London: n.p., 1770.

Orobio de Castro, Isaac. Prevenciones divinas contra la vana idolatria de las gentes, edizione critica, con introduzione, note di commento e riassunti parafrasi in italiano a cura di Myriam Silvera, vol. 1. Florence: L. S. Olschki, 2013.

Popkin, Richard H. "Jacques Basnage's Histoire des Juifs and the Bibliotheca Sarraziana," Studia Rosenthaliana 22 (1987): 154-162.

Révah, I. S. Spinoza et le dr Juan de Prado. Paris and The Hague: Mouton \& Cie., 1959.

Rosenberg, Shalom, and Alexander Even-Chen, "Coplas filosóficas de Abraham Gómez Silveyra." Revue des études juives 153 (1994): 327-351.

Roth, Ernst, and Hans Striedl, Hebräische Handschriften in Deutschland, vol. III. Wiesbaden: n.p., 1984.

Salomon, Herman P. Portrait of a New Christian: Fernão Álvares Melo (1569-1632). Paris: Gulbenkian, 1982.

Salomon, Herman P. Saul Levi Mortera en zijn "Traktaat betreffende de Waarheid van de Wet van Mozes," eigenhandig geschreven in de Portugese taal te Amsterdam 1659-1660. Inleiding, transcriptie en aantekeningen. Braga: Barbosa \& Xavier, 1988.

Saperstein, Marc. Exile in Amsterdam: Saul Levi Morteira's Sermons to a Congregation of "New Jews." Cincinnati: Hebrew Union College Press, 2005.

Sierhuis, Freya. The Literature of the Arminian Controversy: Religion, Politics and the Stage in the Dutch Republic. Oxford: Oxford University Press, 2015.

Steinschneider, Moritz. Catalog der hebräischen Handschriften in der Staatsbibliothek Hamburg. Hamburg: Otto Meisner, 1878.

Van der Haven, Alexander. "Judeo-Christianity and Conversion to Judaism in the Seventeenth-Century Dutch Republic." Lecture at the $17^{\text {th }}$ World Congress of Jewish Studies. Jerusalem, 8 August, 2017.

Van Rooden, Peter T. "A Dutch Translation of Elias Montalto's Tratado sobre o princípio do Capítulo 53 de Jesaias. Text, Introduction and Commentary." Lias 16 (1989): 189-238.

Weiser, Raphael, and Yosef Kaplan, Treasures from the Library Ets Haim-Livraria Montezinos of the "Portuguese Israëlitisch Seminarium Ets Haim," Amsterdam. Jerusalem: Jewish National and University Library, 1980.

Wilke, Carsten L. "Midrashim from Bordeaux: A Theological Controversy inside the Portuguese Jewish Diaspora at the Time of Spinoza's Excommunication." European Journal of Jewish Studies 6.2 (2012): 207-247.

Wilke, Carsten L. The Marrakesh Dialogues: A Gospel Critique and Jewish Apology from the Spanish Renaissance. Leiden: Brill, 2014. 